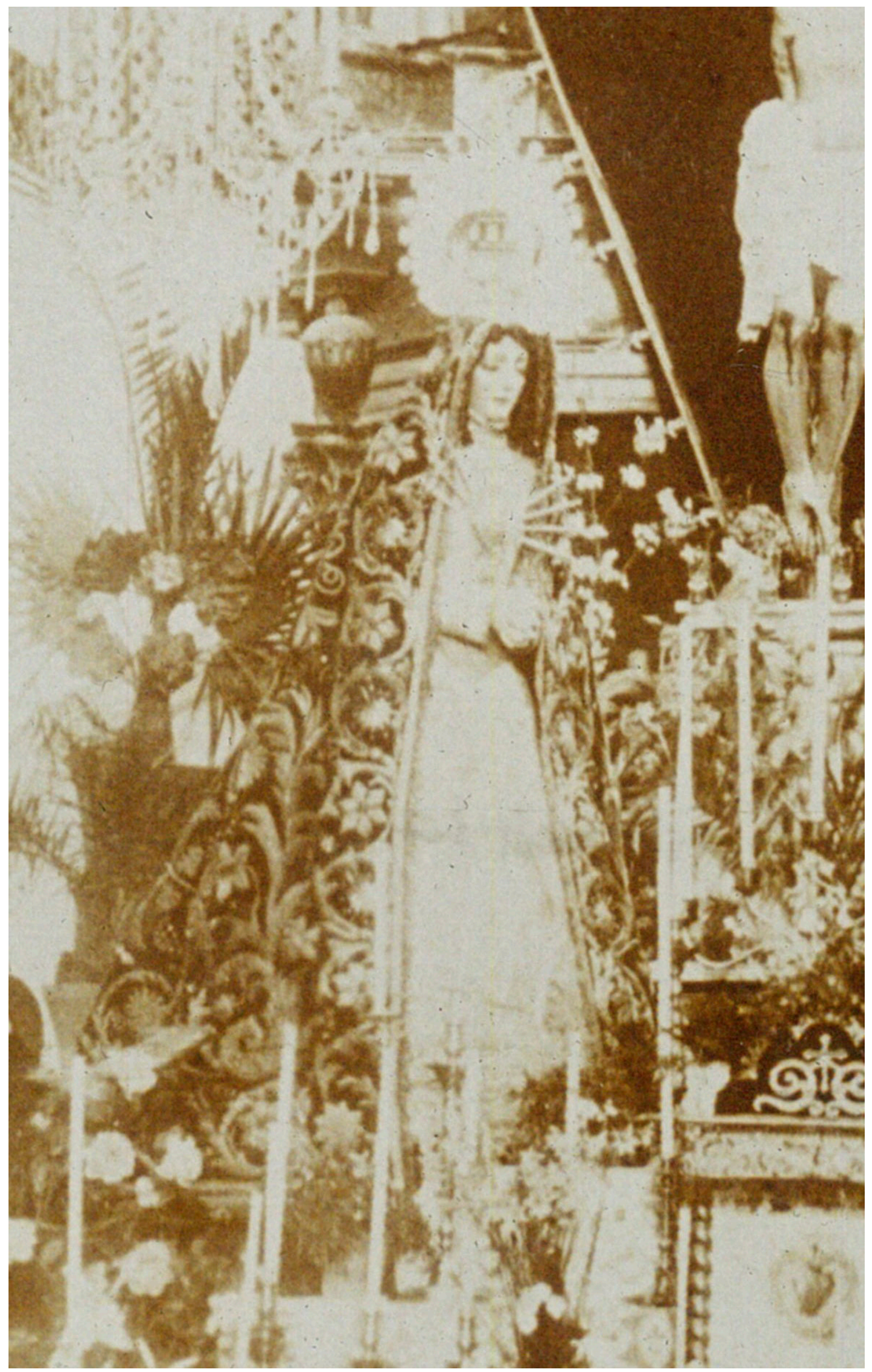

Fig. 1. Andrés de Carvajal (restauración), Virgen de los Dolores, 1759. Desaparecida en la Guerra Civil. (Detalle de fotografía de hacia 1920). 


\section{Noticias sobre artistas antequeranos del siglo XVIII. Entalladores, escultores y doradores al servicio de las cofradías de Campillos}

News about Antequera Artists of the XVIII Century:

Carvers, Sculptors, and Gilders at the service of the Campillos Brotherhoods

Antonio Joaquín Santos Márquez

Universidad de Sevilla, España

anjo@us.es

https://orcid.org/0000-0002-7671-0936

\section{Resumen}

En este estudio se da a conocer una serie de informaciones artísticas localizadas en los libros de cuentas de dos cofradías penitenciales de Campillos, las de la Vera Cruz y el Santo Entierro de Cristo. En concreto, son noticias que evidencian la total renovación que sufrieron sus enseres, gracias principalmente a artistas de Antequera. Por su interés, nos centraremos en las que competen a entalladores, escultores y doradores que ejecutaron para estas corporaciones retablos, esculturas, andas y otros adornos de sus capillas. Noticias inéditas que nos permiten conocer aún mejor la creatividad de Andrés de Carvajal o la de su hijo Miguel María de Carvajal, y también

\begin{abstract}
This study sheds light on new art data discovered in records belonging to the penitential brotherhoods of Vera Cruz and Santo Entierro of Campillos. In particular, the information reveals a total renovation of their equipment, mainly thanks to Antequera artists. Here we will address only unpublished facts regarding sculptures, altarpieces, and their gilding and polychrome made by important artists such as Andrés de Carvajal and his son Miguel Maria de Carvajal. Also, we will highlight the work of previously unknown artists such as sculptors Pedro Martinez de Aguilar, Jerónimo Ruiz, and Francisco Durán.
\end{abstract}

Keywords: news; altarpiece makers; sculptors; gilders; Antequera; 18 th century.

Cómo citar este trabajo / How to cite this paper:

Santos Márquez, Antonio Joaquín. "Noticias sobre artistas antequeranos del siglo XVIII. Entalladores, escultores y doradores al servicio de las cofradías de Campillos." Atrio. Revista de Historia del Arte, no. 25 (2019): 82-97.

(C) 2019 Antonio Joaquín Santos Márquez. Este es un artículo de acceso abierto distribuido bajo los términos de la licencia Creative Commons Attribution-NonCommercial-ShareAlike 4.0. International License (CC BY-NC-SA 4.0). 
aumentar el catálogo de artistas conocido hasta el momento por la historiografía, con los escultores inéditos Pedro Martínez de Aguilar, Jerónimo Ruiz o el prolijo Francisco Durán.

Palabras clave: noticias; entalladores; escultores; doradores; Antequera; siglo XVIII.

El siglo XVIII será un periodo de esplendor para las artes antequeranas. Tan solo hay que recorrer sus calles para evidenciar cómo durante el Barroco se vivió un periodo floreciente en el arte local, llegando a su cenit en dicha centuria, con artistas de gran personalidad que conformaron un verdadero e interesante foco artístico en el centro geográfico de Andalucía. No obstante, hasta tiempos recientes no fue bien entendida la influencia ejercida por estos maestros más allá de sus límites urbanos, circunstancia que se está poniendo en valor en la actualidad, constatándose en una importante creatividad que se localiza en muchas poblaciones hoy ubicadas al sureste de la provincia de Sevilla, sur de la de Córdoba, al noreste de la de Cádiz, al noroeste de la de Granada o en el ámbito nororiental de la provincia de Málaga. ${ }^{1}$

Pues bien, es curioso que donde quizás más desapercibida ha pasado la presencia de estos maestros antequeranos haya sido precisamente en el área más cercana, esto es, en la amplia comarca de Antequera, ya que gran parte de su patrimonio fue arrasado durante la Guerra Civil. ${ }^{2}$ Conocidas son las virulentas consecuencias que esta contienda tuvo en el arte religioso de la provincia de Málaga, también en el norte de la provincia, donde se destruyeron grandes conjuntos patrimoniales, salvándose solo los de Antequera y Archidona. Unas pérdidas que se acrecentaron aún más con la desaparición de sus archivos parroquiales que de igual modo fueron pasto de las llamas. Por ejemplo, ello fue lo que sucedió en localidades cercanas a la ciudad del Torcal como Teba, Cañete la Real o Campillos, cuyo importante patrimonio religioso y documental quedó en su mayor parte destruido en julio de 1936. Basta con entrar en sus magníficas iglesias barrocas para constatar cómo solo ha quedado su arquitectura y algunos restos de retablos, imágenes u objetos de plata, predominando un lamentable vacío que ha sido solventado en parte con nuevos elementos que en su mayoría carecen de calidad artística. Sin embargo, a veces nos llevamos la grata sorpresa de localizar archivos particulares que permiten, al menos de manera parcial, conocer la historia de este legado artístico y sus protagonistas, así como incluso poder identificar entre los restos conservados alguna obra de arte de interés. Ello es lo que sucede con los de las cofradías penitenciales de Campillos, y concretamente con los archivos de la Vera Cruz y del Santo Entierro de Cristo, ${ }^{3}$ pues se salvaron del fuego debido a que dicha documentación se custodiaba en las casas particulares de sus mayordomos. Gracias a esta circunstancia, y tras una exhaustiva lectura especialmente de sus libros de contabilidad, hemos podido constatar que los artistas antequeranos fueron los más demandados durante el siglo XVIII en esta localidad malagueńa, entonces perteneciente a la

\footnotetext{
1. El primer estudio sobre la escultura española que resaltó la importancia de los escultores antequeranos del siglo XVIII fue el de Jorge Bernales Ballesteros y Federico García de la Concha Delgado, Imagineros andaluces de los siglos de oro (Barcelona: Editoriales Andaluzas Unidas SA., 1986), 157-58. Un trabajo que refleja perfectamente este panorama y la influencia de estos artistas en el referido ámbito geográfico es el realizado por José Luis Romero Torres, "La obra escultórica de Andrés de Carvajal y la escultura antequerana," en Cuadernos de Estepa, n. ${ }^{\circ} 4$, Actas del I Congreso Andaluz sobre Patrimonio Histórico. La escultura andaluza en el siglo XVIII. Conmemoración del III Centenario del nacimiento del escultor Andrés de Carvajal y Campos (1709-2009) (Estepa, 17-18 septiembre de 2009) (Estepa: Ilmo. Ayuntamiento de Estepa, 2014), 112-31.

2. José Jiménez Guerrero, La destrucción del patrimonio eclesiástico en la Guerra Civil. Málaga y su provincia (Málaga: Editorial Arguval, 2011).

3. Los libros de cabildos y cuentas de la Cofradía del Santo Entierro fueron solamente transcritos por Pilar Parras Arcas, In Dei Nomine. Libros de la Cofradía del Santo Entierro de Cristo y Nuestra Señora de las Angustias (Campillos, 1648-1879) (Granada: Editorial Tleo, 2016).
} 
archidiócesis de Sevilla. Una demanda que tuvo como finalidad renovar y acrecentar su patrimonio cultual y procesional, y que se pudo gestionar gracias al momento de esplendor económico que vivirán estas corporaciones, reflejo de la prosperidad y desarrollo que la propia villa de Campillos tuvo desde su emancipación de Teba en 1680 hasta la llegada de los inciertos años de la invasión francesa. ${ }^{4}$ En efecto, será un periodo en que las hermandades desarrollaron todo un proceso de renovación, tanto en sus espacios de culto como en el ajuar de sus cortejos procesionales. La cercanía de Antequera evidentemente hizo que estas corporaciones emularan muchas de las costumbres y maneras que se estaban implantando en dicha ciudad y, por esta causa, capillas con suntuosos camarines, retablos dorados de rica imaginería, tronos o triunfos para las andas, coronas de plata, bordados para palios y mantos, y así un largo etcétera, serán demandados en Campillos siguiendo el patrón y el modelo antequerano, siendo el nutrido número de artistas que trabajaron durante este siglo en la ciudad los responsables de su materialización. Cierto es que, en el estudio de investigación que nos ocupa, hemos hecho una selección entre todas estas noticias, ante su elevado número y la extensión que podría ocupar nuestro trabajo. Por esta razón, nos centraremos en el relato de los datos relativos a la entalladura, la escultura y el dorado, exponiendo así toda esta creatividad que, además, en casos muy puntuales, hemos podido vincular con piezas que aún guardan estas hermandades.

\section{El entallador Pedro Martínez de Aguilar}

Las primeras referencias documentales sobre la presencia de entalladores antequeranos trabajando para las cofradías de Campillos datan de la década de 1730. Será en ese momento cuando un artista hasta hoy día desconocido sea contratado por dos hermandades para renovar parte del ajuar de sus capillas y de sus cortejos procesionales. Concretamente nos referimos al entallador Pedro Martínez de Aguilar (doc. 1730-1736), quien debió trabajar en Antequera siguiendo la línea marcada por Antonio Rivera y Miguel Asencio Carrizo, que eran los grandes retablistas de ese momento. ${ }^{5}$ La primera noticia que tenemos de Martínez de Aguilar es la hechura del retablo principal de la capilla de la Cofradía de la Vera Cruz. El encargo lo recibe del mayordomo Alonso de Casasola, probablemente al inicio de su mandato en 1728, pues la obra comienza a ser trasladada a Campillos en 1730. De hecho, el escultor colocó el banco del retablo en ese ańo, lo que costó 23 reales y medio, ${ }^{6}$ siendo ayudado posteriormente por oficiales y carpinteros cuando puso su cuerpo al ańo siguiente, anotándose 158 reales y 17 maravedíes por estas labores en la contabilidad ${ }^{7}$. En 1731 se habían abonado al escultor 3.700 reales, y restaban otros 1.292 para cerrar la cuenta que alcanzó los 8.644 reales, total que se pagó definitivamente en octubre de $1734 .{ }^{8}$ Quedaba así el retablo asentado en el altar del Santo Cristo, sin dorar, y sabemos que estaba compuesto por tres calles, quizás divididas por los estípites típicos de la época, que enmarcarían la hornacina central donde se ubicaba el Crucificado de la Vera Cruz con Ma-

\footnotetext{
4. Sobre la historia de Campillos y su patrimonio se puede consultar Antonio Aguilar y Cano, Apuntes de la Villa de Campillos (Puente Genil: Imp. Y Librería "Estrada y Reina", 1891); Baltasar Peña Hinojosa, Pequeña historia de la villa de Campillos (Málaga: Publicaciones Caja de Ahorro Provincial de Málaga, 1960); Rosario Camacho Martínez, Málaga Barroca. Arquitectura religiosa de los siglos XVII y XVIII (Málaga: Universidad de Málaga, 1980), 519-23; Rosario Camacho Martínez, coord., Inventario artístico de Málaga y su Provincia II (Madrid: Ministerio de Cultura, 1985), 173-77; Ildefonso Herrera Felguera, Miscelánea campillera para el V centenario de su fundación (Málaga: Gráficas San Patricio, 1992); Rosario Camacho Martínez, coord., Guía artística de Málaga y su provincia (II) (Sevilla: Fundación José Manuel Lara, 2006), 131-35.

5. Rosario Camacho Martínez y Jesús Romero Benítez, "Aproximación al estudio del retablo en Antequera en el siglo XVIII," Imafronte, no. 3-4-5 (1987-1988-1989): 347-66.

6. Archivo de la Cofradía de la Vera Cruz de Campillos (en adelante ACVCC). Segundo libro de mayordomía 1728-1782, cuentas del 11 de abril de 1728 a 31 de mayo de 1731, data, f. 5v

7. ACVCC. Segundo libro de mayordomía 1728-1782, cuentas del 11 de abril de 1728 a 31 de mayo de 1731, data, 5v.

8. ACVCC. Segundo libro de mayordomía 1728-1782, cuentas del 11 de abril de 1728 a 31 de mayo de 1731, data, f. 5 v.; cuentas del $1^{\circ}$ de octubre de 1734 al 31 de mayo de 1736, data, f. 22r; inventario del 3 de abril de 1736, f. 19v.
} 
ría Magdalena a sus pies, mientras que en las calles laterales se ubicaban las imágenes de Jesús Resucitado, probablemente la ejecutada por Andrés de Iriarte en 1596, y San Juan Evangelista, según se describe en el inventario de 1742. ${ }^{9}$ Centraba el ático la figura del Dios Padre, rodeado de seis ángeles pequeños, dos ellos con tarjetas encarnadas que recogían en letras de oro posiblemente el anagrama de Cristo. ${ }^{10}$

Precisamente esta misma corporación, una vez finalizado el retablo del Santo Cristo en 1734, le encomendó un nuevo proyecto. En concreto unas andas "con trono de talla y seis varas y 13 angelitos y diez horquillas", conjunto que estaba ya acabado para abril de 1736 y tuvo un coste de 1.500 reales de vellón. ${ }^{11}$ Este nuevo trono de la Virgen de los Dolores en principio permaneció unos años en madera vista, hasta que fue dorado y encarnados sus ángeles durante el verano de 1742 (concretamente en 120 días) por el pintor y dorador Juan Francisco de Leyva, vecino de Campillos, cobrando por su trabajo 720 reales de vellón, y por el oro y colores otros $1.099 .{ }^{12}$ Además, el mismo entallador realizó los seis varales de madera que sostenían el cielo del palio que, al igual que la "camilla" o faldones de las andas, era de terciopelo negro. ${ }^{13}$

Un triunfo de talla que debió ser semejante al que igualmente labró para la Cofradía del Santo Entierro, en cuya contabilidad en el mismo 1736 su mayordomo anota que "Para la Imagen de Ma SSma. de las Angustias se hicieron unas Andas nuevas de escultura con su trono, tres angeles y vidrieras con seis varas que se ajustaron con d. Pedro Martínez Mo escultura q costaron un mil seiscientos y cinquenta costa de recibo". ${ }^{14}$ De igual modo, fue dorado entre 1743 y 1747 , siendo su coste de 2.648 reales y desconociéndose en este caso quien hizo esta labor. ${ }^{15}$

Unas entalladuras de tronos que coinciden en el tiempo con la incorporación de las imágenes marianas a los cortejos procesionales en la Semana Santa de Campillos, cuya concordia para su inclusión, ordenamiento y organización se firmó entre las cofradías penitenciales el 2 de abril de $1736 .{ }^{16}$ Sin lugar a dudas esta fue la razón de ser de ambas peanas que, si bien no se conservan, no tenemos la menor duda que reproducían el modelo de triunfo bajo palio que se estaba plenamente asentando en Antequera durante el Barroco, y cuyos ejemplos más elocuentes y significativos los tenemos en los tronos antequeranos de la Virgen de la Paz (1682) y de la Virgen de los Dolores (h. 1702), obras del escultor Antonio del Castillo, sin duda el creador de esta tipología tan singular de la ciudad del Torcal. ${ }^{17}$

\section{El escultor Andrés de Carvajal}

Mucho más conocido es el escultor que trabajó para la Cofradía de la Vera Cruz en la década de 1760. Nos referimos a Andrés de Carvajal (1709-1779), al cual recientemente Jesús Romero Benítez ha dedicado una monografía donde se pone en valor su intensa creatividad en todo el ámbito territorial que hemos referido

\footnotetext{
9. ACVCC. Segundo libro de mayordomía 1728-1782, inventario del 21 de enero de 1742, f. 22v.

10. La descripción del retablo se recoge en el inventario de 1782. ACVCC. Segundo libro de mayordomía 1728-1782, inventario de 3 de marzo de 1782, f. 127r.

11. ACVCC. Segundo libro de mayordomía 1728-1782, inventario del 3 de abril de 1736, f. 19v.

12. ACVCC. Segundo libro de mayordomía 1728-1782, cuentas de mayo de 1741 a mayo de 1743 , cargo f. 30 v., data, $31 \mathrm{v}$.

13. ACVCC. Segundo libro de mayordomía 1728-1782, inventario del 1 de noviembre de 1746, f. $43 v$.; cabildo e inventario del 23 de marzo de 1782 , f. 128 r.

14. Archivo de la Cofradía del Santo Entierro de Cristo de Campillos (en adelante ACSECC), Libro Primero de Cabildos y Cuentas Generales. 1648-1797, cuentas del 30 de septiembre de 1734 al 31 de enero de 1737, ff. 68r-68v.

15. ACSECC., Libro Primero de Cabildos y Cuentas Generales. 1648-1797, cuentas del 9 de marzo de 1743 al 1 de agosto de 1746, f. $78 v$.

16. ACVCC. Segundo libro de mayordomía 1728-1782, Acuerdo de conformidad zelebrado por los May. ${ }^{\text {mos }}$ y oficiales de las quatro cofradias de Semana S. ${ }^{\text {ta }}$ para el orden que se a de observar en los sitios que hace de ocupar en las procesiones y llevar las ymagenes, 2 de abril de 1736, ff. 14r-15v.

17. Jesús Romero Benítez, Antonio del Castillo escultor antequerano 1635-1704 (Antequera: Chapitel, 2013), 71-77.
} 
en un principio. ${ }^{18} \mathrm{Y}$ sin duda, en esta época fue el escultor de cabecera de esta hermandad, pues a lo largo de más de una década se le encomendará la construcción de un trono para el Santo Cristo de la Vera Cruz, la renovación de su titular mariana la Virgen de los Dolores, y la ejecución de una nueva Magdalena.

El primero de sus trabajos fue la entalladura del nuevo trono que presumiblemente se le encargó a mediados de 1759, abonándole el mayordomo de la Vera Cruz para comenzar la obra 1.500 reales. ${ }^{19}$ Este debió estar concluido al año siguiente, aunque no será hasta el ajuste de las cuentas de esos años, presentadas el 19 de diciembre de 1763, cuando se informó que se le habían abonado todos los reales hasta llegar a los 5.500 ajustados en la tasación del trabajo. ${ }^{20}$ Desafortunadamente, en el inventario posterior no se describe de manera detallada, aunque pudo ser similar al que también ejecutó este mismo artista para el Santo Cristo de la Salud y las Aguas, patrono de Antequera, en 1762, y que parece ser el que aún utiliza la imagen en su trono de palio neogótico, compuesto por un alto pedestal a manera de pilar donde encaja la cruz y se apoyan cuatro patas angulares en forma de "S" a base de gruesas volutas, todo ello con entalladura de rocalla y siguiendo la tipología de triunfo en pirámide. ${ }^{21}$ Además, Carvajal añadió al trono del Santo Cristo el característico palio de respeto que se convirtió en la seña de identidad de la Semana Santa antequerana desde el siglo XVII ${ }^{22}$. Precisamente, en el concierto de las andas se incluían seis varales de madera tallada y dorada, ${ }^{23}$ y se pagaron otros 672 reales en Antequera por dieciséis varas de felpa verde para confeccionar "el zielo de las andas del Señor". ${ }^{24}$ Una imagen del Santo Cristo de la Vera Cruz bajo palio que podemos recrearla precisamente con el Crucificado de la Salud y las Aguas, o en el Nazareno de la Sangre que aún hoy conserva su palio en su procesión del Martes Santo antequerano. Y además, en esta misma corporación, se conserva un antiguo palio bordado que perteneció a su otro titular, el Santo Cristo Verde, que aparece por primera vez mencionado en el inventario de 1706, aunque por su estilo se puede fechar a mediados del siglo XVII. ${ }^{25}$ Por lo tanto, Antequera será de nuevo el espejo donde se mire esta cofradía campillera, ya que serán sus cofrades los que demanden este modelo para su Crucificado de la Vera Cruz. Y en efecto, cuando se describe en el inventario de 1782 se dice que tenía "un palio de felpa verde para las andas del $S .{ }^{\text {or }}$ con sus senefas de madera", lo que nos permite aventurar que pudo tener también unas cornisas de talla dorada que le daban estabilidad a la estructura superior y que fueran ejecutadas asimismo por Carvajal. ${ }^{26}$ Una labor de entalladura que además no era conocida hasta el momento entre los quehaceres del maestro, pues, de hecho, Jesús Romero dudaba de su predisposición a realizar este tipo de trabajos, algo que viene a ser desmentido con estos dos tronos referidos. ${ }^{27}$

La siguiente intervención de este escultor acontece cuando estaba ejecutando la referida entalladura del triunfo procesional. La llevó a cabo en la Virgen de los Dolores, una imagen de candelero que debió llegar igualmente de algún taller antequerano en la década de 1720, momento en el que se tiene constancia de la apertura de su nicho en la capilla de la Vera Cruz y la adquisición de los diferentes elementos de su ajuar,

18. Jesús Romero Benítez, El escultor Andrés de Carvajal (1709-1779) (Antequera: Chapitel, 2014).

19. ACVCC. Segundo libro de mayordomía 1728-1782, cuentas del 16 de octubre de 1756 al 26 de julio de 1759, f. $79 \mathrm{v}$.

20. ACVCC. Segundo libro de mayordomía 1728-1782, cuentas de 24 de julio de 1759 a 19 de diciembre de 1763, f. 82v. Si tenemos en cuenta que en la data este apunte aparece entre los primeros, posiblemente pudieron estar acabadas en 1760.

21. José Escalante Jiménez, El puzle de la Historia (Antequera como paradigma) (Antequera: ExLibris, 2014), 85

22. Consultar el interesante trabajo de Jesús Romero Benítez, "El paso de palio antequerano: evolución y formas," Revista Nazareno (1988): 137-43.

23. Lo sabemos pues, dos de estas varas no entraron en el ajuste de las andas, y costaron su hechura y dorado 470 reales. ACVCC. Segundo libro de mayordomía $1728-1782$, cuentas de 24 de julio de 1759 a 19 de diciembre de 1763, f. 83 r.

24. ACVCC. Segundo libro de mayordomía 1728-1782, cuentas de 24 de julio de 1759 a 19 de diciembre de 1763, ff. 83v-84r.

25. Antonio Fernández Paradas, "Teoría y Praxis del trono antequerano. Estética, diseño y definición de un discurso," en Antequera y su Semana Santa, coord. José Escalante Jiménez (Antequera: ExLibris, 2015), 138-39, 166.

26. ACVCC. Segundo libro de mayordomía 1728-1782, Cabildo e inventario del 23 de marzo de 1782, f. 129r.

27. Romero Benítez, El escultor Andrés de Carvajal, 36. 
tanto textiles como de orfebrería. Será precisamente a mediados del siglo XVIII, cuando se levante su capilla propia, en un solar junto a la de la Vera Cruz que fue donado por el Ayuntamiento en $1736^{28}$. Pues bien, en el transcurso de estas obras, concretamente en el mismo año 1759, la aludida imagen de vestir de la Dolorosa tuvo un "lastimoso daño" debido "averse desplomado y caído el basamento de yeso sobre que descansava y aver dado la señora de cara en la capilla desprendiéndose todo a el suelo". Por esta causa, fue llevada al escultor para que le volviera a encarnar el rostro y por ello le abonaron 115 reales. ${ }^{29}$ Cierto es que en la referida anotación no se identifica al referido artista, pero la alusión al mismo como "el escultor", nos permite reconocer a Carvajal, pues era el escultor que estaba trabajando para la hermandad, y ante la cantidad abonada no dudamos que su intervención fuese importante. Desgraciadamente, esta fue una de las imágenes que perecieron en el incendio de 1936 y la conocemos por fotografías no muy buenas, aunque suficientes para poder apreciar a través de ellas los grafismos del citado maestro (Fig. 1).

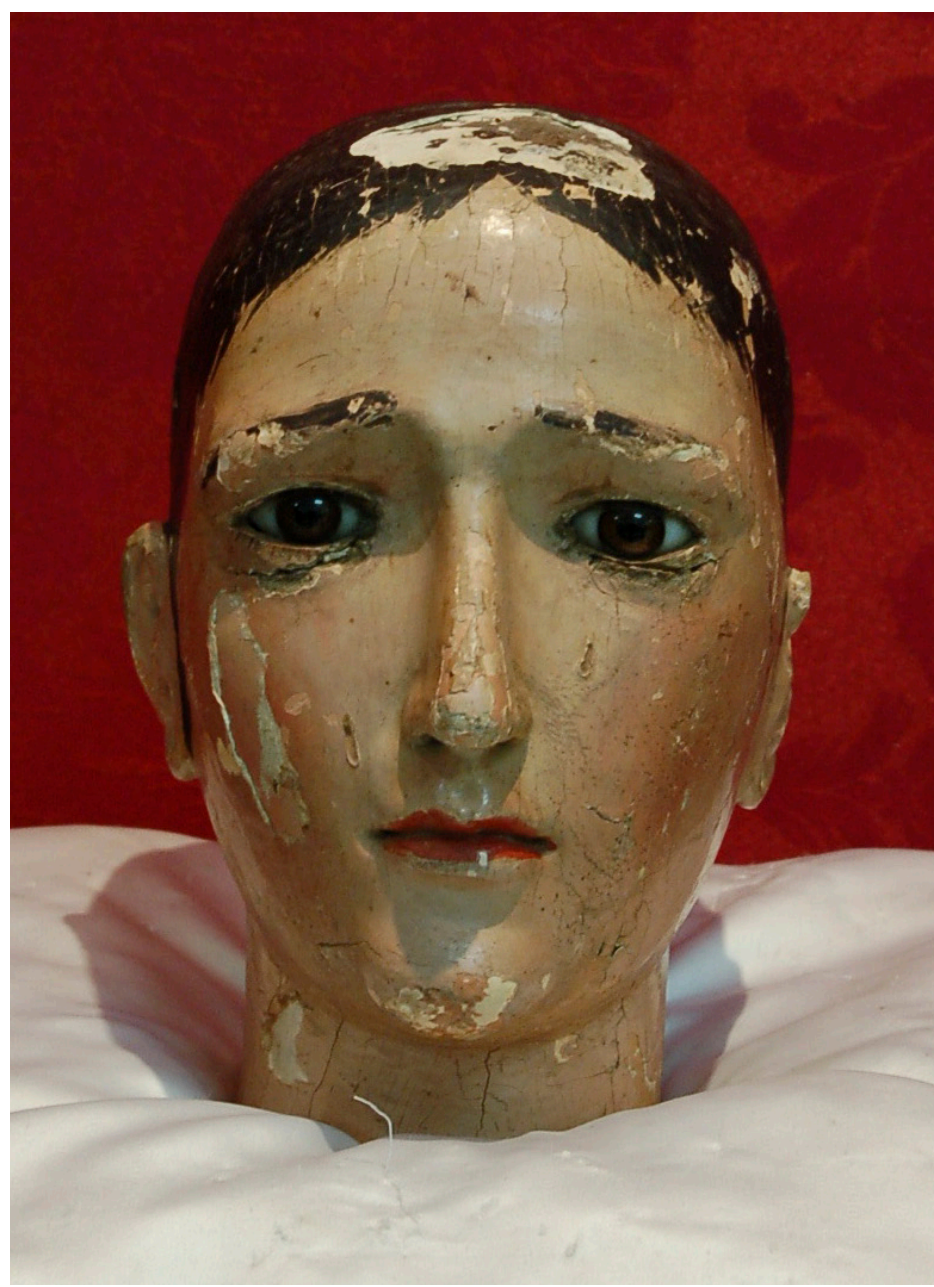

Fig. 2. Andrés de Carvajal, Cabeza de María Magdalena, 1770. Escultura encarnada y policromada, $30 \times 20 \mathrm{~cm}$. Hermandad de la Vera Cruz de Campillos. Su rostro de perfecto óvalo debió ser hermoseado por una nariz recta y fina, unos ojos almendrados, con párpado superior marcado en un pliegue, surco suborbital en "v" ahondando en el dolor, unos salientes pómulos, un mentón algo acusado y con hoyuelo, y su boca resuelta con carnosos labios entreabiertos dejando entrever los dientes, que normalmente los realizaba con postizos de hueso o marfil, aunque evidentemente este último punto no lo hemos podido $\operatorname{comprobar}^{30}$. Lo único que la aparta a las dolorosas de Carvajal es que no inclina su cabeza, producto del mantenimiento del carácter envarado de la escultura original. No sabemos hasta qué punto pudo alterar su imagen la segunda restauración conocida, ejecutada por Joaquín Márquez y Angulo en 1844, aunque al incluirse dentro de una intervención global sobre todas las imágenes de la cofradía, creemos que no debió tener consecuencias muy relevantes sobre esta dolorosa. ${ }^{31}$

28. Herrera Felguera, Miscelánea campillera, 254.

29. ACVCC. Segundo libro de cabildos, visitas e inventarios 1728-1782, cuentas del 16 de octubre de 1756 al 26 de julio de 1759 , f. 78

30. Romero Benítez, El escultor Andrés de Carvajal, 83-84

31. ACVCC. Cuarto libro de mayordomía 1838-1859, cuentas de 24 de mayo de 1844 a 30 de marzo de 1845 , s. f. Este escultor pertenece a la familia de artista iniciada por su abuelo Diego Márquez Vega (1726-1791) y continuada por su hijo Miguel Márquez (1767-1826). Joaquín Márquez restauró todas las imágenes de la cofradía y cobró por ello, ver el estudio de José Escalante Jiménez, "Joaquín Márquez y Ángulo, maestro escultor. Notas biográficas," Pregón Semana Santa 1996 (1996): 49-54. 


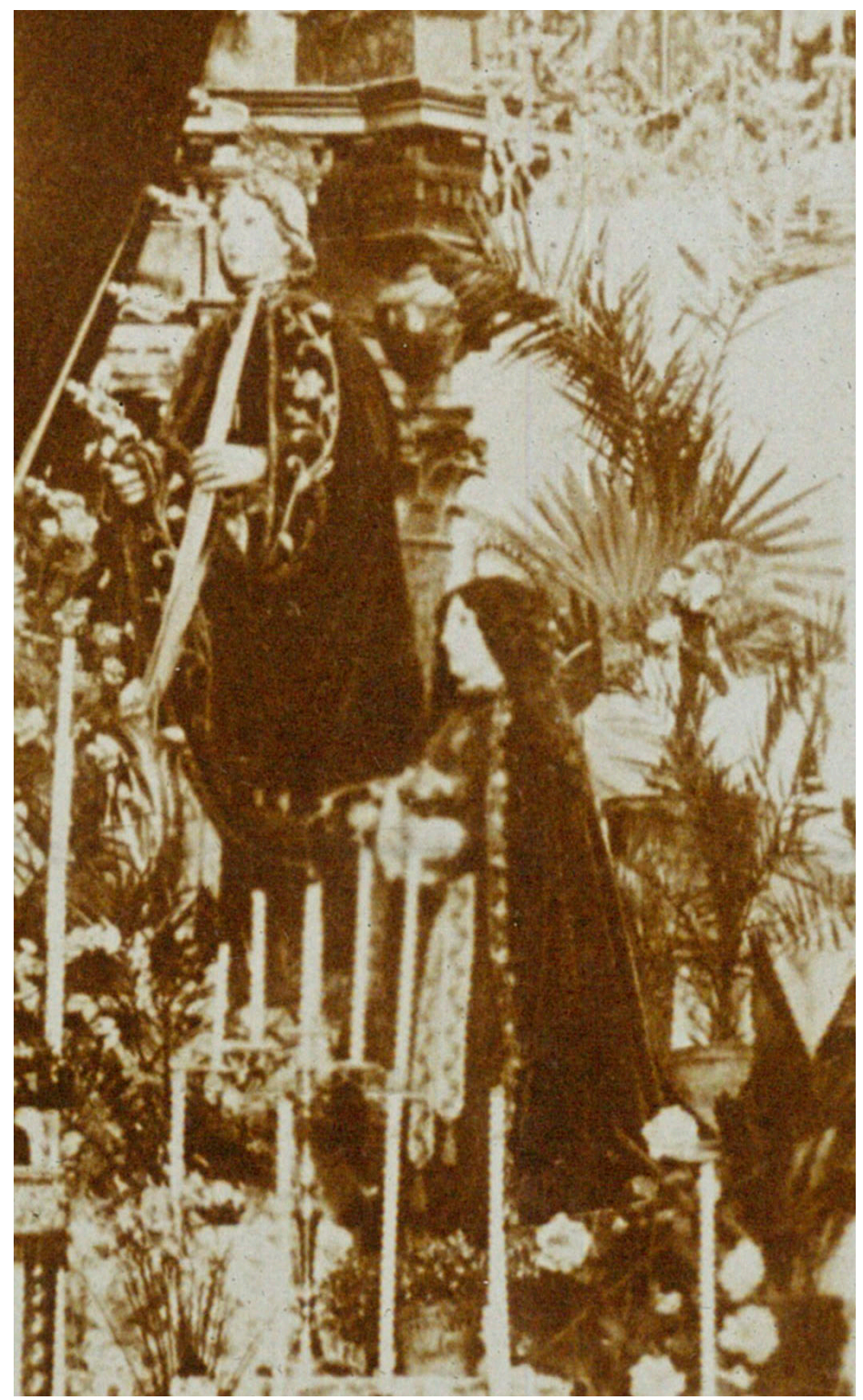

Fig. 3. Andrés de Carvajal, María Magdalena, 1770. Candelero destruido en la Guerra Civil. (Detalle de fotografía de hacia 1920).
Y pensamos que la restauración de Carvajal debió ser importante, pues la misma cofradía le pagó 240 reales por la hechura de una imagen de vestir de María Magdalena, es decir, solo el doble para una creación ex novo. ${ }^{32}$ De hecho, mientras que en la otra intervención consistió solo en rehacer el rostro de la Dolorosa, aquí el escultor debía tallar la cabeza y las manos, encarnarlas y hacer el candelero de esta imagen arrodillada, que portaba en sus manos el tarro de ungüentos típico de su iconografía. Además, este es el caso en que la fortuna, a pesar del saqueo de 1936, hizo que quedase al menos su cabeza, siendo la única creación del afamado escultor antequerano que ha quedado en Campillos (Fig. 2). Su cabeza ovalada, de rasgos dulcificados y algo inexpresivos, presenta unas delicadas mejillas de grandes ojos almendrados y cristalinos, los cuales están enmarcados con unas cejas de arqueamiento diagonal que van a concentrar toda la expresión de dolor, pues en esta ocasión su boca está totalmente cerrada. Unos grafismos que fueron habituales en la obra del maestro, incluso en la manera de resolver las orejas, simplemente esbozadas y con el agujero para incorporar pendientes. Además, su estado originario lo podemos conocer a través de fotografías antiguas, donde la vemos con su larga peluca y ataviada con ricas prendas decimonónicas bordadas (Fig. 3).

\section{El entallador Jerónimo Ruiz}

Este afán renovador de la Cofradía de la Vera Cruz no fue tampoco extraño al resto de instituciones religiosas de la población, encabezadas por la propia parroquia de Santa María del Reposo que en esos años reconstruía y ampliaba su templo, levantándose además su magnífico imafronte barroco, obra proyectada

32. "Se le abonan Doscientos y quarenta rr. gastados y pagados a $D^{\text {n }}$ Andres de Carbajal escultor de la ziudad de Antequera por la Ymagen de $\mathrm{S}^{\text {ta }}$ Maria Mag. . $^{\text {n" }}$ ACVCC. Segundo libro de mayordomía 1728-1782, cuentas del 27 de julio de 1769 al 21 de junio de 1773, data de 1770, f. 108r. 


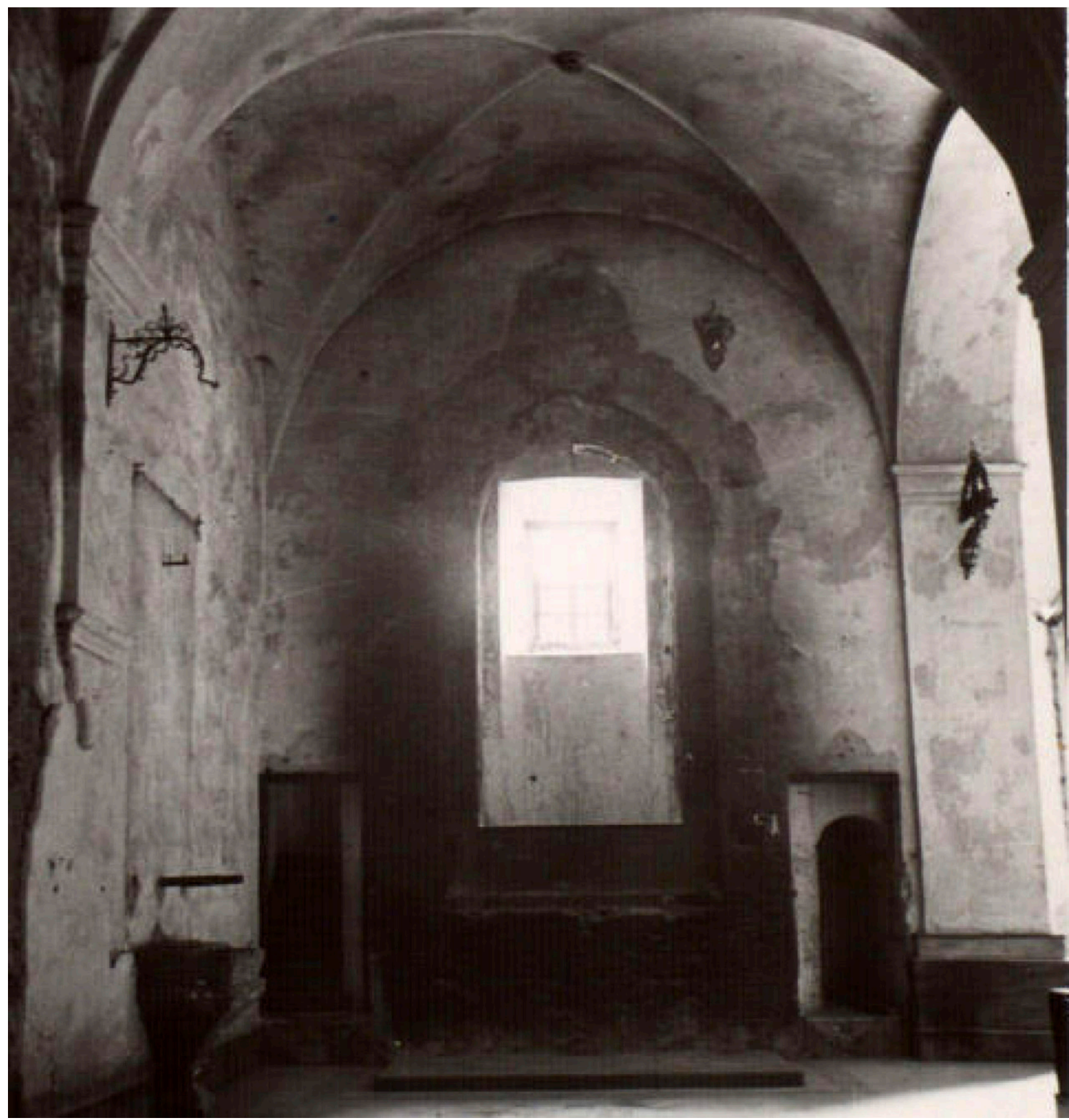

Fig. 4. Antonio de Figueroa, Capilla de la Virgen de las Angustias. Parroquia de Santa María del Reposo, 1772-1774. Se puede apreciar la huella del antiguo retablo de Jerónimo Ruiz. (Fotografía tomada en septiembre de 1936, tras la destrucción de su retablo y enseres. Biblioteca Nacional de España).

por Ambrosio de Figueroa en 1769 y terminada por su hijo Antonio en $1774 .{ }^{33}$ Y como hemos dicho, este movimiento de transformación barroca también afectó al resto de hermandades, tal y como lo atestiguó el propio mayordomo de la Cofradía del Santo Entierro don Pedro Carballo en el cabildo que se celebró el 24 de agosto de 1778:

33. Juan Antonio Arenillas, Ambrosio de Figueroa (Sevilla: Diputación de Sevilla, 1993), 59-60. 
cada una de las hermandades cittas en ella procuraban esmerarse en el culto de sus respectivas imágenes, por lo que se habían construido y estaban construyendo retablos en sus altares y que caresiendo el de estta cofradía de estte adorno, con el deseo que lo asistía a cumplir con el cargo de el empleo de tal Mayordomo y de ver las imágenes titulares de esta cofradía con el mayor culto y desensia, como assi mismo teniendo presente los fondos con que de presente se halla esta cofradía, había tocado la especie de un retablo nuevo con Geronimo Ruiz, maestro tallista de la ciudad de Antequera, quien en el dia estaba concluiendo igual obra para el altar de Jesús Nazareno, cita en dicha iglesia, por quien se le habia entregado el diseño de que hacia manifestación para su conocimiento de los hermanos de la cofradía. ${ }^{34}$

Una declaración que nos informa de la existencia de un entallador desconocido para la historiografía como es el antequerano Jerónimo Ruiz (doc. 1778-1783), a quien adjudica la autoría del desaparecido retablo del Nazareno, que estaba siendo colocado en su capilla en ese mismo momento, y que fue el referente para que el aludido mayordomo lo eligiera como el más indicado para ejecutar el proyecto de retablo del altar de las Angustias, que además había sido totalmente renovado y ampliado tras levantarse su camarín precisamente por el arquitecto Antonio de Figueroa entre 1772 y $1774 .{ }^{35}$ Así pues, mostrado el diseño del retablo a los hermanos y "haviendo inspeccionado, y visto estar mui dencente y segun arte segun el cono-

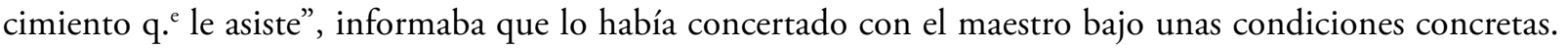
Estas se centraban en el tiempo de ejecución de la obra y en su financiación. El retablo debía estar terminado y entregado en tres años y su valor total debía ser de 2.600 reales de vellón, pagados de la siguiente manera: el primer pago de 866 reales con 22 maravedíes se lo harían cuando estuviese terminado y puesto el primer cuerpo según el diseño convenido; la segunda parte de lo estipulado sería abonada cuando hubiese colocado el segundo cuerpo; y el remate final, tras las mismas formalidades de inspección y siempre que se ajustase al dicho dibujo preparatorio, debía ser entregado cuando se colocase el tercer cuerpo del retablo. El maestro se comprometía a asumir dichos requisitos y a no solicitar más dinero a la cofradía, incluyendo que, si se le diese alguna gratificación final, esta fuese asumida por el propio mayordomo. Cierto es que, si pensamos en el muro donde fue dispuesto, con el arco que se abría al camarín de Antonio de Figueroa, creemos que no fue de grandes dimensiones. El referido en la documentación como primer cuerpo hacía referencia al banco, delante del que se debía disponer la urna para el Señor de la Buena Muerte, tal y como se le nombra al titular en esta época. Sobre este basamento se levantaría el marco arquitectónico de estípites y rocallas que sería el segundo cuerpo, con repisas para imágenes como veremos a continuación, y el tercero haría referencia al ático que lo remataba. De hecho, esa es la huella que se percibe en las fotografías que se hicieron tras su destrucción en la Guerra Civil (Fig. 4). Y a pesar de lo estipulado en la contratación de la obra, en las cuentas de los años siguientes se registran los pagos a Jerónimo Ruiz de una manera más aleatoria que la prefijada en la escritura. Así, en la data del año siguiente se anota el pago de 1.000 reales de vellón al entallador y otros 80 reales por la "conducion de la Repiza del Retablo en un carro como asimismo el maestro tallista y dos oficiales para rematarla desde dha ciudad de Antequera" ${ }^{36}$ Este término "repiza" sería un sinónimo utilizado en la época para referirse al banco o basamento de la estructura del retablo. Hay que esperar a las cuentas presentadas el 3 de mayo de 1782, para volver a encontrar otra anotación de pago por esta causa, ahora valorado en 300 reales de vellón simplemente a cuenta de su trabajo. ${ }^{37}$ Será en las registradas el 3 de junio

\footnotetext{
34. ACSECC. Libro Primero de Cabildos y Cuentas Generales. 1648-1797, Cabildo del 24 de agosto de 1778, ff. 122v-134r.

35. ACSECC. Libro Primero de Cabildos y Cuentas Generales. 1648-1797. En 1772 se hacen los cimientos del camarín. Se contabiliza el pago a Antonio Figueroa Maestro mayor de las obras que se están practicando en la Parroquia 1.600 reales, en 1773, (ff. 118v-119) y se pagan en 1774 otros 500 reales "por quenta de la q executo en el camarin de esta cofradía" (f. 121v).

36. ACSECC. Libro Primero de Cabildos y Cuentas Generales. 1648-1797. Cuentas del 1 de mayo de 1778 al 15 de agosto de 1779 , f. $137 \mathrm{v}$.

37. ACSECC. Libro Primero de Cabildos y Cuentas Generales. 1648-1797. Cuentas del 26 de mayo de 1781 al 3 de mayo de 1782 , f. 144.
} 
de 1783 donde se cierre la cuenta y se le abonen los 1.300 reales que faltaban para alcanzar la cifra comprometida en el contrato, especificándose por ello que "se concluye el todo en q. ${ }^{\text {e }}$ fue ajustado, y da su finiquito el dho maestro Geronimo Ruiz". ${ }^{38}$ A esta cifra se añadieron los 80 reales "por el costo de alimentos, porte y condu $^{\text {on }}$ del maestro y tres oficiales q. ${ }^{\text {e }}$ estuvieron ocho días, en la construcción y sentar dho. Retablo" ${ }^{39}$ Por lo tanto, si bien no se cumplieron los tiempos de pago tal y como se habían fijado en el contrato, sí se llegó a la referida cifra de 2.600 reales e igualmente se cumplió el plazo de tres años prefijado en el mismo para su colocación en el altar de la Cofradía del Santo Entierro.

\section{El escultor Joaquín García}

De un escultor más conocido hemos localizado igualmente un trabajo en la contabilidad de la Cofradía de la Vera Cruz. Nos referimos concretamente al escultor malagueño Joaquín García (doc. 1787-1792), quien primero se asentó en Ronda, para trasladarse luego a Antequera donde desarrollará su actividad en las últimas décadas del siglo. ${ }^{40}$ De ahí que, en 1789 , esta hermandad de Campillos solicitase sus servicios para esculpir dos ángeles lampareros destinados a enmarcar el retablo mayor de la capilla del Santo Cristo y por los que recibió 2.060 reales. ${ }^{41}$ Seguramente, tras la ejecución de estas obras, el escultor vio posibilidades de trabajo en una parroquia en plena renovación estética, y de ahí que fuese uno de los maestros que presentaron un diseño para el proyecto de Monumento de Jueves Santo que la fábrica quería ejecutar en 1792. Y además, en defensa de su proyecto, argumentó que había realizado varias esculturas para Campillos y que había "cumplido con el mayor exmero y equidad”, aludiendo precisamente a que sus últimas creaciones habían sido los dos ángeles lampareros de la capilla del Santo Cristo. ${ }^{42}$

\section{El escultor y dorador Francisco Durán}

El maestro más demandado por las hermandades de Campillos en el último cuarto del siglo XVIII será el escultor y dorador Francisco Durán (doc.1774-1797), otro ignoto artista hasta el momento, cuya creatividad se centrará en la entalladura y su dorado, y en la escultura, su policromía y su estofado. En concreto, trabajará especialmente para la Cofradía de la Vera Cruz y en menor medida para la del Santo Entierro. Su aparición en Campillos coincide con la reconstrucción de la capilla de la Vera Cruz en 1774 llevada a cabo por el alarife antequerano José Durán, quien igualmente será el responsable de levantar el nuevo camarín donde se venerará a partir de ese momento este Crucificado. ${ }^{43}$ Pues bien, Francisco será el encargado de desmontar el antiguo retablo de Martínez de Aguilar, y llevarlo a Antequera para agrandarlo y adaptarlo a las medidas que presentaba el nuevo frente donde se abría el camarín. Por este trabajo recibió la cantidad de 1.671 reales, ${ }^{44}$ y una vez colocado el retablo el mismo artista procedió a su dorado, que aún no se había llevado a cabo, percibiendo igualmente

38. ACSECC. Libro Primero de Cabildos y Cuentas Generales. 1648-1797. Cuentas del 20 de mayo de 1782 al 3 de junio de 1783, f. $147 \mathrm{v}$.

39. ACSECC. Libro Primero de Cabildos y Cuentas Generales. 1648-1797. Cuentas del 20 de mayo de 1782 al 3 de junio de 1783 , f. 148.

40. Sobre este escultor ver Andrés Llordén, Escultores y entalladores malagueños. Ensayo histórico documental (siglos XV-XIX) (Ávila: Ediciones Real Monasterio de El Escorial, 1960), 338.

41. ACVCC. Tercer libro de mayordomía 1783-1835, cuentas 16 de mayo de 1786 al 28 de enero de 1790, Data del año $1789, f .41$.

42. Francisco S. Ros González, "Obras y proyectos de la familia Acosta en Campillos (Málaga)," Laboratorio de Arte, no. 25 (2013): $630-32$.

43. ACVCC. Segundo libro de mayordomía 1728-1782, cuentas del 23 de junio de 1773 al 20 de noviembre de 1778, ff. 117v-118r.

44. ACVCC. Segundo libro de mayordomía 1728-1782, cuentas del 23 de junio de 1773 al 20 de noviembre de 1778, f. 119r. 
por este concepto la elevada cantidad de 7.100 reales en $1778 .{ }^{45}$ El resultado debió gustar a la cofradía, pues en 1781 a este mismo artista le encargó el dorado del retablo de la Virgen de los Dolores, además del encarnado y policromado de sus ángeles y serafines. Por este trabajo cobró la elevada cantidad de 6.000 reales, a los que añadió otros 224 reales por el dorado y los listeles azules que aplicó a los candelabros y atriles del altar del santo Cristo y al atril del altar de la Virgen. ${ }^{46}$ Además, en 1783 entregó a la misma cofradía seis basamentos para las pilastras esquineras del camarín de la Virgen de los Dolores, recibiendo por ello 3.047 reales de vellón, y otros 400 reales por pintar las dos puertas interiores de este recinto, las chapinas de color jaspeado, el dorado del marco de la bula de indulgencias de la Virgen, y el dorado y jaspeado del tarimón donde se alzaba esta dolorosa. ${ }^{47}$ Además, junto a estas labores se le abonaron otros 84 reales por el barnizado y rotulación de los nombres de los apóstoles en las diademas que llevaban los figurantes del apostolado que procesionaba en el cortejo de la estación de penitencia, costumbre también proveniente de Antequera. ${ }^{48}$

De igual modo, en 1783 fue contratado por la Hermandad del Santo Entierro. Ahora recibió 538 reales de vellón por "la hechura de dos santos con sus diademas y escalas, y asimismo, dos Angeles, q. ${ }^{\mathrm{e}}$ adornan el retablo, y su porte. ${ }^{39}$ Por lo tanto, recayó en Durán la ejecución de la imaginería del retablo de Jerónimo Ruiz, lo cual además nos permite imaginar su posible estructura, pues los santos irían en repisas a los lados del arco central del camarín, y los ángeles se ubicarían en el ático, esquema bastante común en los retablos antequeranos de la época. Y además a este mismo escultor se pudo deber la urna de talla para la imagen del Cristo yacente que el mayordomo de esta hermandad registró este mismo año y por la que abonó 235 reales de vellón. ${ }^{50}$

Una labor escultórica que debió gustar entre los cofrades de Campillos, pues de nuevo la Hermandad de la Vera Cruz recurrirá a sus servicios para la hechura de los cuatro evangelistas destinados al adorno del trono del Santo Cristo en 1784, y por las que se le abonaron otros 1.049 reales. ${ }^{51}$ Estas figuras posiblemente estarían dispuestas en los ángulos de las andas sobre unas basas de madera tallada y dorada que fueron hechas por el mismo entallador en $1785,{ }^{52}$ y que, según se desprende de los inventarios, tras la procesión se colocaban enmarcando en el camarín al Crucificado, de ahí su destrucción en 1936. A esta imaginería se le añadieron cuatro diademas y cuatro pequeñas plumas, todas de plata y labradas igualmente en Antequera en $1784 .{ }^{53}$ Dos de estas diademas aún se guardan en el tesoro de la cofradía, único testimonio de estas esculturas, cuya hechura responde a los diseños propios de la rocalla.

No será hasta 1790, cuando esta hermandad vuelva a abonarle otros 1.000 reales en esa ocasión por un concepto muy diferente. Ahora, le compraba una lámina en la que se representaba a la Virgen de los Dolores entregando el santo escapulario a los siete fundadores florentinos de la Orden Servita, un testimonio que delata su probable faceta como pintor. ${ }^{54}$ Además, para esta lámina el afamado platero antequerano Félix de Gálvez y Sánchez (d. 1752-1803), ${ }^{55}$ labró una pequeña coronita para colocarla sobre la cabeza de la ima-

45. ACVCC. Segundo libro de mayordomía 1728-1782, cuentas del 23 de junio de 1773 al 20 de noviembre de 1778, f. 121v.

46. ACVCC. Cuentas sueltas de la cofradía, data de 1781, f. 30v.

47. ACVCC. Tercer libro de mayordomía 1782-1835, cuentas desde febrero de 1782 al 16 de mayo de 1786, f. 23.

48. ACVCC. Tercer libro de mayordomía 1783-1835, cuentas desde febrero de 1782 al 16 de mayo de 1786, f. 23 v.

49. ACSECC. Libro Primero de Cabildos y Cuentas Generales. 1648-1797, cuentas del 15 de junio de 1783 al 30 de mayo de 1784 , f. 149

50. ACSECC. Libro Primero de Cabildos y Cuentas Generales. 1648-1797, cuentas del 15 de junio de 1783 al 30 de mayo de 1784 , f. 149

51. ACVCC. Tercer libro de mayordomía 1783-1835, cuentas desde febrero de 1782 al 16 de mayo de 1786, f. 25r.

52. ACVCC. Tercer libro de mayordomía 1783-1835, cuentas desde febrero de 1782 al 16 de mayo de 1786, f. 27r.

53. ACVCC. Tercer libro de mayordomía 1783-1835, cuentas desde febrero de 1782 al 16 de mayo de 1786, f. 26r.

54. ACVCC. Tercer libro de mayordomía 1782-1835, cuentas del 30 de mayo de 1790 a 6 de septiembre de 1793, data del año 1790 , f. 52.

55. Rafael Sánchez-Lafuente, El Arte de la Platería en Málaga 1550-1800 (Málaga: Junta de Andalucía-Universidad de Málaga, 1997), $357-58$. 
gen mariana, junto a otra aureola de plata que también ejecutó para otra estampa que se colgó en la capilla del Santo Cristo, y que representaba al Cristo del Mayor Dolor, aquella devota imagen que donara Andrés de Carvajal en 1771 a la colegiata de Antequera. ${ }^{56}$

Según recibo del 4 de abril de 1793, a Durán y a su oficial Agustín Muriel se le darán otros 154 reales por la hechura de doce nuevas diademas doradas y rotuladas para el apostolado de la procesión de la Vera Cruz. ${ }^{57}$ Además, también se encargará de restaurar y dorar el trono que labró Andrés de Carvajal para la Virgen de los Dolores, cobrando por ello 540 reales el 3 de abril de $1794 .{ }^{58}$

La última intervención conocida del maestro llegará en 1797. En ese año se le abonaron dos trabajos importantes que rematarían la decoración de la capilla del Santo Cristo de la Vera Cruz. En primer lugar, ejecutó cuatro pilastras de madera dorada para las esquinas de la capilla. Por esta labor se le entregaron 4.200 reales, completándose este nuevo ańadido ornamental con unos basamentos de jaspe encarnado, en esta ocasión labrados por el cantero estepeño Francisco Muñoz y con un coste de 3.450 reales. ${ }^{59}$

El segundo de los trabajos fue la ejecución de un nuevo retablo para esta misma capilla. Como a continuación comentaremos, la renovación de la imagen del Resucitado en 1797 supuso igualmente la apertura de un nuevo nicho en la pared lateral del recinto y la ejecución de un retablo hornacina, compuesto por un marco tallado y dorado con un sencillo coronamiento, pues se le abonaron solo 600 reales por este concepto, a lo que habría que añadir la vidriera que cerraba el nicho que fue ejecutada también en Antequera y costó 160 reales. ${ }^{60}$

\section{El escultor Miguel María de Carvajal}

Un retablo que, como hemos dicho, fue realizado para la nueva imagen de Jesús Resucitado, la cual fue encargada a otro escultor, en este caso mucho más conocido por la historiografía especializada en el tema, como es Miguel María de Carvajal (1757-1818). El hijo del gran maestro Andrés de Carvajal y heredero de su taller, en estos años finales de la centuria copaba junto a Miguel Márquez gran parte del mercado escultórico antequerano $^{61}$. La fama de su buen hacer determinó su elección en 1797 para esculpir la referida imagen, por la que cobró 1.200 reales de vellón, más otros 100 por su traslado a Campillos. ${ }^{62}$ Esta escultura venía a sustituir a otra que durante años se había venerado en la capilla del Santo Cristo, como ya comentamos en una calle lateral del retablo de Martínez de Aguilar, y que posiblemente fuera la que realizara el escultor antequerano Andrés de Iriarte y luego policromara Juan Vázquez de la Vega entre 1595 y $1596 .{ }^{63}$ La decisión de ser suplantada por esta nueva obra parece que se debió a una serie de problemas que habían surgido con su propiedad, tras ser cuestionada esta por el visitador episcopal hispalense don Antonio Labáiros en la visita del 4 de octubre de $1782 .{ }^{64} \mathrm{La}$ hermandad, ante esta situación, intentó argumentar que la antigua escultura le era propia, en tanto aparecía en

56. ACVCC. Tercer libro de mayordomía 1782-1835, cuentas del 30 de mayo de 1790 a 6 de septiembre de 1793, data del año 1790, f. 52.

57. AHVCC. Tercer libro de mayordomía 1783-1835, 30 de mayo de 1790 a 16 de septiembre de 1793. Data de 1791, 1793, f. 53r.

58. ACVCC. Tercer libro de cabildos, visitas e inventario 1782-1806, cuentas del 3 de octubre de 1793 y el 8 de mayo de 1796, f. 63r.

59. ACVCC. Tercer libro de mayordomía 1783-1835, cuentas del año 1797, f. 73r.

60. ACVCC. Tercer libro de mayordomía 1783-1835, data de 1797, f. 75.

61. José Escalante Jiménez, "Miguel María de Carvajal y Talavera. Apuntes biográficos," Pregón. Semana Santa 1997 (1997): 53-57; Romero Benítez, El escultor Andrés de Carvajal, 227-42.

62. ACVCC. Tercer libro de mayordomía 1783-1835, data de 1797, f. 73 v.

63. José Escalante Jiménez, "El círculo escultórico antequerano del siglo XVI," Revista de estudios antequeranos, no. 2 (1993): $341,347$.

64. ACVCC. Segundo libro de mayordomía 1728-1782, Nota de la visita del 4 de octubre de 1782, f. 130 
los inventarios más antiguos que tenían de sus bienes. No obstante, parece que esta explicación no convenció a la autoridad eclesiástica, que finalmente determinó que el Resucitado era propiedad de la parroquia. La posterior reacción de la cofradía fue de reafirmación de su vinculación a esta advocación, incorporándola incluso al título de la hermandad cuando se produjo el nombramiento del nuevo mayordomo en ese mismo año, en cuyo inventario se registra por primera vez la intitulación "de la capilla de la Sta, Vera Cruz y Resurrección titular de esta cofradía." ${ }^{65}$ E incluso se mantuvo en su reivindicación, cuando de nuevo aparece como principal advocación de esta corporación en la redacción de las nuevas ordenanzas para su fusión obligada con la Hermandad Sacramental en $1801 .{ }^{66}$ Por esta razón, no es de extrañar que el mayordomo Juan Gallego tuviese la determinación de hacer la nueva imagen ante la enajenación de la antigua, para que no hubiese ninguna duda que era propiedad indiscutible de la Hermandad de la Vera Cruz. Y para que quedase constancia de ello, tras la llegada de la escultura a Campillos, hizo que Miguel María de Carvajal firmara un protocolo de entrega y titularidad ante el escribano local José Ramos de Arjona el 30 de julio de dicho año, para así "colocarlo en el sitio donde se hallaba el que actualmente tiene la Fabrica de esta dha iglesia." ${ }^{67}$ Por lo tanto, se le perdía el rastro a la imagen manierista y en su lugar se veneraría esta nueva hechura tardobarroca que ocuparía el retablo hornacina ejecutado por Durán, y para la cual además se labraron unas potencias de plata, un trabajo del orfebre antequerano Antonio Durán y Toro, quien recibió por ellas 240 reales de vellón. ${ }^{68}$ Desafortunadamente, pocas son las referencias posteriores a esta imagen, a excepción de la alusión a su existencia en el inventario parroquial de 1884 y en el de $1907^{69}$, siendo pasto de las llamas en 1936 junto al resto de esculturas, retablos y enseres de esta capilla.

Una última aportación con la que cerramos este capítulo de noticias inéditas sobre la actividad de estos artistas en Campillos durante el siglo XVIII, el cual es testimonio escrito, como decíamos en un principio, de un rico patrimonio hoy desgraciadamente desaparecido, y a su vez es otra prueba fehaciente de la relevancia que adquirió Antequera durante esta centuria como verdadera capital artística del centro geográfico de Andalucía.

\section{Documento}

\section{Apéndice documental}

Campillos. 1797, julio, 30.

Carta de pago y cesión de propiedad de la imagen de Jesús Resucitado por parte de su artífice, don Miguel María de Carvajal, al mayordomo de la Cofradía de la Vera Cruz don Juan Gallego Moreno, su contratante.

ACVCC. Carpeta de documentos sueltos. Carta de pago y cesión de la imagen de Jesús Resucitado.

Sepase como yo Dn. Miguel María de Carvajal vezino de la ciudad de Antequera artífice de Escultor en ella residente a el presente en esta villa de Campillos digo: que el may. ${ }^{\text {mo }}$ y oficiales y otros cofrades de la Cofradía de el Santisimo Christo de la Vera Cruz esta en esta Iglesia Parroquial convinieron conmigo en que les hisiese una efigie de el Señor Resusitado para colocarlo en el sitio donde se hallaba el que actualmente tiene la Fabrica de esta dha Yglesia o donde mas bien acomodase a dicha cofradía y habiendo cerrado el contrato, y ofresidome satisfacer por dha. efigie, un mil y doscientos rr. v. ${ }^{\text {on }} / /$ vajo de este

65. ACVCC. Segundo libro de mayordomía 1728-1782, Cabildo del 16 de febrero de 1782, f. 124.

66. ACVCC. Documentos sueltos. Borrador de las reglas de la Cofradía de la Vera Cruz para su fusión con la Hermandad Sacramental. 1801.

67. ACVCC. Documentos sueltos. Título de propiedad de la imagen del Resucitado ante el escribano José Ramón Arjona en Campillos el 30 de julio de 1797, s. f.

68. ACVCC. Tercer libro de mayordomía 1783-1835, data de 1797, f. 74.

69. AGAS. Sección Justicia, Serie Inventarios, Legajo 15640, doc. n. ${ }^{\circ}$ 6, inventarios de 1884 y 1907. 
seguro procedi y en efecto he dado concluida la Ymagen de Ntro. Señor Resusitado y he trasladado a esta Villa y Casas de el actual mayordomo de dicha cofradía D. ${ }^{\mathrm{n}}$ Juan Gallego Moreno; y en atención a que este de los caudales de dha. cofradía, me ha reintegrado de los expresado un mil y doscientos rr. v. ${ }^{\text {on }}$ me ha pedido de que para la seguridad de la misma ahora y en todo tiempo; y que tenga titulo de la Propiedad de dicha imagen otorgue la correspondiente escritura de carta de pago y sesion en forma lo que poner justo he tenido a bien, y poniendolo en practica, confesando como confieso la relación que antesede por cierta y verdadera, por el tenor de la presente otorgo, que he recivido de mano // de el dich D. ${ }^{\mathrm{n}}$ Juan Gallego Moreno como tal mayordomo, y de los caudales de la dicha cofradía, los expresados un mil y doscientos rr. ${ }^{\text {on }}{ }^{\text { }} \mathrm{q}$ ha tenido de costo hasta su conclusión la Ymagen de dho Señor Resusitado, y por ser y para en mi poder realmente y con efecto y no parecer de pres. ${ }^{\text {te }}$ su entrega, renuncio la excepción de la non numerata pecunia, la ley nueve titulo primero partida quinta q. ${ }^{e}$ de ella trata, y los dos años que prefine para la prueva de un recivo que doy por pasados, como si lo estuvieren y otorgo a favor de nra cofradía, y en su nombre de el expresado Dn. Juan Gallego Moreno como tal su mayordomo el resguardo mas eficaz q. ${ }^{\mathrm{e}}$ a su seguridad convenga; y a su consequensia deste oy dia de la fha. de esta escriptura en adelante, y para siempre jamás me desapodero, desisto, quito y aparto de todo el derecho, y acción de propiedad posesión y señorío que tenía y me pertenecia a la dicha Ymagen de el Señor Resusitado q. ${ }^{e}$ he traído, y existe en esta dicha villa, a disposición de dha cofradía y todos ellos, con los de evicción seguridad y saneamiento, los cedo, renuncio y transfiero en la misma, para que dha. Ymagen sea siempre de su propiedad havida y adquirida con justo y lexitimo titulo como lo es este Exx. ${ }^{\text {na }}$ y cesion que le hago a dicha Cofradia bien y cumplidam. ${ }^{\text {te }}$ con todas las clausulas, fuerzas y firmezas de dro. aun mayor estabilidad y doy aquí por insertas, e incorporadas de verbo adverbum; de manera que // a mi como tal su artifise y mediante la satisfacción que de su coste se me ha dado no me queda acción la mas remota a pedir por dha Ymagen a dha Cofradía cosa alguna, y si lo intetare a los mios consiento no se nos oyga en juicio antes bien se nos expeta de el, y condene en costas como a injustos y temerarios litigantes; y por el mimo hecho ha de ser visto a ver aprobado y ratificado esta ess.na ańadiendo a ella fuerza a afuerza, y contrato a contrato y a la mayor firmeza de ella, consiento se me execute y apremie por todo rigor de nro. via executiva y de apremio, en virtud de esta escritura su traslado o testimonio y lexitimo juramento // en el que lo dejo, y queda diferido y de prueba relevado, desisorio como si lo fuese en juicio contradictorio; y a lo asi cumplir y a ver por firme obligo mi persona y bienes havidos y por a ver y doy poder cumplido a las justicias y jueces de S. M. que de mis causas puedan conocer y especial y señaladamente a las desta villa, a cuio fuero y jurisdicción me someto y renuncio a el mio propio, domicilio, y vecindad que de pres.te tengo en dha. ciudad de Antequera y otro que de nuevo pueda adquirir con la ley si Convenerit de Iurisdictione onmium Iudicum, y las ultimas nuevas Pragmaticas e las sumisiones, y salarios, para que a lo referido me compelan y apremien como por sentencia pasada en autoridad// de cosa juzgada por mi consentida y no apelada en firmeza de lo qual renuncio todas las leyes fueros y dros. de mi defensa y favor y la q. ${ }^{\mathrm{e}}$ prohíbe gral. Renunciasion en forma, y como se contiene otorgo la pre. ${ }^{\text {te }}$ ante el Ess. ${ }^{\text {no }}$ pp.$^{\text {co }}$ del numero y Ayuntamiento de esta villa de Campillos y testigos en cuio rexistro lo firme, que es hecha en ella a treinta de Julio de mil setezientos noventa y siete años siendo presentes por testigos D. ${ }^{\mathrm{n}}$ Benito de Herrera, Martín Ximenez de Rueda y D. ${ }^{\mathrm{n}}$ Juan Fran.co de Arjona vezinos desta villa ; e yo el Ess. ${ }^{\text {no }}$ doy fe conozco a el otorgante-

Miguel María Carvajal

Ante mi Dn. Jose Ramon de Arjona escrivano.

Referencias

Aguilar y Cano, Antonio. Apuntes de la Villa de Campillos. Puente Genil: Imp. Y Librería "Estrada y Reina”, 1891.

Arenillas, Juan Antonio. Ambrosio de Figueroa. Sevilla: Diputación de Sevilla, 1993. 
Bernales Ballesteros, Jorge, y Federico García de la Concha Delgado. Imagineros andaluces de los siglos de oro. Barcelona: Editoriales andaluzas Unidas SA., 1986.

Camacho Martínez, Rosario, coord. Inventario artístico de Málaga y su Provincia II. Madrid: Ministerio de Cultura, 1985.

---. Guía artística de Málaga y su provincia (II). Sevilla: Fundación José Manuel Lara, 2006.

Camacho Martínez, Rosario, y Jesús Romero Benítez. "Aproximación al estudio del retablo en Antequera en el siglo XVIII.” Imafronte, no. 3-4-5 (1987-1988-1989): 347-66.

Camacho Martínez, Rosario. Málaga Barroca. Arquitectura religiosa de los siglos XVII y XVIII. Málaga: Universidad de Málaga, 1980.

Escalante Jiménez, José. "El círculo escultórico antequerano del siglo XVI." Revista de estudios antequeranos, no. 2 (1993): 341, 347.

---. “Joaquín Márquez y Ángulo, maestro escultor. Notas biográficas." Pregón Semana Santa 1996 (1996): 49-54.

---. "Miguel María de Carvajal y Talavera. Apuntes biográficos." Pregón. Semana Santa 1997 (1997): 53-57.

---. El puzle de la Historia (Antequera como paradigma). Antequera: ExLibris, 2014.

Fernández Paradas, Antonio. "Teoría y Praxis del trono antequerano. Estética, diseño y definición de un discurso.” En Antequera y su Semana Santa, coordinado por José Escalante Jiménez, 149-89. Antequera: ExLibris, 2015.

Herrera Felguera, Ildefonso. Miscelánea campillera para el V centenario de su fundación. Málaga: Gráficas San Patricio, 1992.

Jiménez Guerrero, José. La destrucción del patrimonio eclesiástico en la Guerra Civil. Málaga y su provincia. Málaga: Editorial Arguval, 2011.

Llordén, Andrés. Escultores y entalladores malagueños. Ensayo histórico documental (siglos XV-XIX). Ávila: Ediciones Real Monasterio de El Escorial, 1960.

Parras Arcas, Pilar. In Dei Nomine. Libros de la Cofradía del Santo Entierro de Cristo y Nuestra Señora de las Angustias (Campillos, 1648-1879). Granada: Editorial Tleo, 2016.

Peña Hinojosa, Baltasar. Pequeña historia de la villa de Campillos. Málaga: Publicaciones Caja de Ahorro Provincial de Málaga, 1960.

Romero Benítez, Jesús. “El paso de palio antequerano: evolución y formas.” Revista Nazareno (1988): 137-43. ---. Antonio del Castillo escultor antequerano 1635-1704. Antequera: Chapitel, 2013.

---. El escultor Andrés de Carvajal (1709-1779). Antequera: Chapitel, 2014.

Romero Torres, José Luis. "La obra escultórica de Andrés de Carvajal y la escultura antequerana." En Cuadernos de Estepa, no. 4, Actas del I Congreso Andaluz sobre Patrimonio Histórico. La escultura andaluza en el siglo XVIII. Conmemoración del III Centenario del nacimiento del escultor Andrés de Carvajal y Campos (1709-2009) (Estepa, 17-18 septiembre de 2009), 112-31. Estepa: Ilmo. Ayuntamiento de Estepa, 2014.

Ros González, Francisco S.. "Obras y proyectos de la familia Acosta en Campillos (Málaga).” Laboratorio de Arte, no. 25 (2013): 623-42.

Sánchez-Lafuente, Rafael. El Arte de la Platería en Málaga 1550-1800. Málaga: Junta de Andalucía-Universidad de Málaga, 1997.

Fecha de recepción: 17/09/2018

Fecha de revisión: 24/09/2018

Fecha de aceptación: 28/01/2019 